\title{
How to make beta cells from embryonic cells
}

\author{
R. Scharfmann
}

Published online: 19 September 2006

(C) Springer-Verlag 2006

Many recent publications have considered the generation of mouse or human pancreatic beta cells from embryonic stem (ES) cells. Some groups have claimed that existing protocols are already capable of generating mature beta cells from ES cells, whereas others have questioned the global strategy employed, the reproducibility of such studies and the interpretation of their results.

Soria and co-workers published the first report of insulin-producing cells derived from mouse ES cells in 2000 [1]. Their protocol was based on a drastic selection of insulin-transcribing cells, and its efficiency was low. It was however a first and important step. Some months later, McKay and co-workers reported generation of beta cells from ES cells using a protocol similar to that used to generate neurons from ES cells [2]. Further studies enhanced the efficiency of this strategy [3,4], but these reports soon came in for criticism. It was questioned whether beta-like cells derived from ES cells ever transcribe the insulin gene [5]. Further debate revolved around whether protocols designed to produce or select for neural progenitors should be used at all, rather than trying to recapitulate the normal sequence of molecular signals that occur during physiological beta cell development [6]. Such points are discussed in detail in this debate [7,8].

P. Serup is an expert in the field of beta cell development. He presents a pessimistic view of the question [7]. He begins by examining the first report of derivation of insulin-producing cells from mouse ES cells [1], and focuses on the limitations of this work. He next considers three papers in which insulin-containing cells

R. Scharfmann $(\bowtie)$

Faculty of Medicine, INSERM, Necker Hospital,

University Paris-Descartes,

EMI 363,

75730 Paris cedex 15, France

e-mail: scharfmann@necker.fr were differentiated from mouse ES cells via the differentiation of progenitors that express nestin [2-4], a method previously developed to generate neurons from mouse ES cells. It is important to bear in mind that the rationale underlying such protocols is based on the observed similarity between beta cells and neurons. Here again, Serup offers a robust critique, and refers to three papers that strongly suggest that insulin-containing cells arise from nestin-positive progenitor cells as a result of uptake of exogenous insulin, rather than as a consequence of biosynthesis $[5,6,9]$. He concludes that the best way to generate beta cells is to replicate beta cell ontogeny, and describes important new developments in this area.

A. Wobus is an expert in the field of ES cells. She has established methods for culturing and differentiating ES cells into a range of differentiated cell types, including most recently, into pancreatic beta cells [4]. Her view is more optimistic [8], and starts from the contention that beta cells can indeed be generated from ES cells using protocols developed to generate neurons from mouse ES cells. She proposes that such insulin-transcribing cells represent ectoderm-derived insulin-producing cells, in contrast to pancreatic beta cells, which derive from endoderm. Ectoderm-derived insulin-producing cells would synthesise insulin, but at low levels, and their secretion would not be regulated by glucose.

My personal view of the problem is that we are far from being able to generate beta cells from ES cells. Papers published in scientific journals a few years ago gave the impression that there were protocols available to enable the generation of functional beta cells from ES cells. This information also appeared in the newspapers. It now seems that such published work is extremely difficult to reproduce, or that the cells produced, far from being beta cells able to produce, store and secrete insulin upon glucose stimulation, actually produced low amounts of insulin in an 
unregulated manner. Equally, many subsequent studies have dissected the different steps of beta cell development that take place during embryonic life. We have learned a lot about this complex process, but much remains to be discovered. I believe that it is crucial to continue to dissect this complex process, and to use such knowledge to reproduce the physiological steps of beta cell development with ES cells. The first step on this pathway, as Serup describes, was to generate endoderm from ES cells. The next step will be to generate pancreatic progenitors, then endocrine progenitors, and finally beta cells, derived from such endodermal cells.

\section{References}

1. Soria B, Roche E, Berna G, Leon-Quinto T, Reig JA, Martin F (2000) Insulin-secreting cells derived from embryonic stem cells normalize glycemia in streptozotocin-induced diabetic mice. Diabetes 49:157-162

2. Lumelsky N, Blondel O, Laeng P, Velasco I, Ravin R, McKay R (2001) Differentiation of embryonic stem cells to insulin- secreting structures similar to pancreatic islets. Science 292: 1389-1394

3. Hori Y, Rulifson IC, Tsai BC, Heit JJ, Cahoy JD, Kim SK (2002) Growth inhibitors promote differentiation of insulin-producing tissue from embryonic stem cells. Proc Natl Acad Sci USA 99: $16105-16110$

4. Blyszczuk P, Czyz J, Kania G, Wagner M, Roll U, St-Onge L, Wobus AM (2003) Expression of Pax4 in embryonic stem cells promotes differentiation of nestin-positive progenitor and insulinproducing cells. Proc Natl Acad Sci USA 100:998-1003

5. Rajagopal J, Anderson WJ, Kume S, Martinez OI, Melton DA (2003) Insulin staining of ES cell progeny from insulin uptake. Science 299:363

6. Hansson M, Tonning A, Frandsen U et al (2004) Artifactual insulin release from differentiated embryonic stem cells. Diabetes 53:2603-2609

7. Serup P (2006) Embryonic stem cell-based therapy - a long road to travel. Diabetologia. (in press) DOI 10.1007/s00125-006-0434-x

8. Rolletschek A, Kania G, Wobus AM (2006) Generation of pancreatic insulin-producing cells from embryonic stem cells'Proof of principle', but questions still unanswered. Diabetologia. (in press) DOI 10.1007/s00125-006-0441-y

9. Sipione S, Eshpeter A, Lyon JG, Korbutt GS, Bleackley RC (2004) Insulin-expressing cells from differentiated embryonic stem cells are not beta cells. Diabetologia 47:499-508, Epub February 2004:2014 